\title{
NO ISLAND IS AN ISLAND: PARTICIPATORY DEVELOPMENT PLANNING ON THE CROATIAN ISLANDS
}

\author{
N. STARC \& P. STUBBS \\ The Institute of Economics, Zagreb, Croatia.
}

\begin{abstract}
This text provides an overview of the history of attempts to introduce participatory development planning on the Croatian islands. Within the study of islands, there has been little attention to islands in countries undergoing post-socialist transition. Similarly, within the study of post-socialist strategic development planning, there has been almost no attention to islands. This study addresses both the resilience of islands and their heightened susceptibility to change, borrowing a periodisation from political economies of contemporary Croatia which emphasise the significance of multiple transitions. The text explores island development within socialist Yugoslavia, with islands subsumed within wider processes of industrialisation, urbanisation and, later, coastal tourism. As Croatia's independence was inextricably linked to war, a crisis-induced authoritarian centralism also mitigated against islanders becoming development subjects. The post-war picture, marked as it is by a slow process of integration into EU norms and practices, shows the gap between the legislative rhetoric and the on the ground practice of participatory development planning. The text concludes that, thus far, only the top down element of strategic planning in terms of island development has been implemented, and this itself in a distorted, contradictory, and highly inconsistent, way.
\end{abstract}

Keywords: Croatia, Islands, participation, planning.

\section{INTRODUCTION}

Development has to be managed. This requirement has been so widely acknowledged as to become almost trivial, even to neo-liberals. The choice of what kind of development in a particular case is somewhat less trivial, however. If it is about sectors of the economy the main role is usually reserved for the state. If it is about space i.e. about regions and sub-regions of a particular country, development policy is necessarily shared between different levels of governance. Regardless of the level they are acting at, regional policy makers usually follow some common sense objectives such as sustainable use of a region's resources, full employment, and so on. However, each region will require a policy tailored to its development specificities as the meanings of sustainability and the institutional capacities capable of achieving it may differ significantly, as may development levels [1]. Indeed, regional specificities are numerous and subtle, relating to natural resources, population structure, economic and social history, demographics, and so on. It is increasingly clear that governmental policy makers have to share their regional development management role with everybody that is involved in and /or affected by these policies. Only in this way are specificities addressed, information shared, and appropriate measures taken. By all means desired in a truly democratic environment, the democratization of regional development management also appears as a necessary condition for the sustainable use of resources. Despite this commonsense, empirics shows that such straightforward, almost trivial, arguments are so often neglected or even deliberately disregarded in existing regional policies. We seek to address this paradox through a study of the Croatian islands. The title is an ironic reflection on a line from John Dunne's 1624 Meditation XVII 'No man is an island; entire of itself'. In the sense of isolation from other forces and people, we contend that: 'No island is an island' either.

Islands appear as a specific region par excellence. A couple of islets in the middle of the ocean, or an archipelago along the coast of a continent, share similar specificities. Easily penetrated 
ecosystems, autarchic economies, unique cultures and fragile social structures call for specific development care. If left alone in the sea, islanders know how to manage. Once involved in a wider spatial division of labor, exposed to various disembarkations and offered new possibilities, islanders as a rule cannot cope with the new situation. In such cases (very few islands of the world are still "mainland development free"), an island autarchic economy becomes part of the mainland economy whereas a small island society becomes a part of continental social and institutional structures. By the same token islands become subjected to continental development policies and far too often are faced with continental policy makers disregarding the specificities of the place they have disembarked on.

It is thus not surprising that islands have become more and more attractive to researchers. In the context of the growth of 'island studies' exploring "the constitution of 'islandness' and its possible or plausible impact on ... policy foci/issues" [2], studies of sustainable island development have grown apace. Researchers have addressed planning in the context of the paradox of islands' simultaneous 'vulnerability' and 'resilience' [3]. This literature views islands as 'singularly intriguing' [4], in terms of their diverse ecologies, entrenched peripheral status, sets of socio-economic dislocations, and the experimental and innovative nature of their governance. The earliest studies, from the 1960s, focused primarily on economic development and viability, tending to conflate islands with small peripheral jurisdictions, with an exploration of islands in the context of sustainable development not gaining ground until much later. Summing up the literature, a leading exponent of island studies has suggested that "islandness is an intervening variable that does not determine, but contours and conditions, physical and social events in distinct, and distinctly relevant, ways" [5].

A major focus in the literature has been one which addresses the relation between islandness and modes of governance, posing the question "is island vulnerability exacerbated when systems of governance are imposed from outside?" [6]. A recent focus on 'nissology' or 'the study of islands on their own terms' [7] has sought to bring back questions of human agency into the research, countering a rather deterministic view of islands as "victim(s) of those economic, social, environmental and political factors that characterize thinly populated, isolated jurisdictions" [6]. Although it is the case that "many island populations are internally fragmented about whether and to what extent they should conserve or develop ... resources" [3], the literature has increasingly sought to emphasise the 'imaginative' qualities of islands, their assets and resourcefulness of their inhabitants, framed by their connectedness as much, if not more, than their 'isolation' [8].

The recent economic and social history of the Croatian islands reveals almost all the paradoxes found in the discipline of nissology. Almost everything that can happen to an archipelago has happened: undesired disembarkations, overseas emigration and depopulation, ill conceived policies, and lately the conjunction of war and transition. It also shows what happens when islanders are not consulted and what happens when they do participate.

The last point is particularly important because it opens up the question of island development management as a specific topic within the study of local development planning. Local development has been the subject of a significant comparative literature, linking planning theory, empirical research and practice. Part of this literature has focused on the specific practice of strategic development planning as "a systematic method for dealing with change, consensus building covering the entire community and the creation of a shared vision" [9]. Strategic planning has been seen as concerned with "the harnessing of economic, social, environmental and cultural assets" [10], in an holistic and integrated process, "as equal segments of one development" [11]. In recent times, the literature has begun to recognise that 'the political-institutional dimension' [12] is crucial, with the quality of governance a key intervening variable effecting the outcomes of sustainable development 
planning processes [13]. The role of diverse stakeholders, or "everyone in an area who has an interest in the development of the area" [14], has also been seen as increasingly important, with specific attention to participation as "a process through which stakeholders influence and share control over development initiatives and the decisions and resources which affect them" [15]. An extensive literature has charted the limits and possibilities of stakeholder participation in strategic development planning processes, analysing a range of factors which may influence planning processes and outcomes.

After the fall of the Berlin Wall in 1989, another growth area in the literature has been the issue of local strategic development planning in post-communist transition contexts. Here, the literature has, primarily, focused on the management of sustainable development in post-communist cities, in the context of a paradigm shift in the nature of the socio-economic system, in central-local relations, and in the nature of the planning process. In terms of the latter, the importance of multi-level, pluralistic planning, replacing 'top-down' centralised planning has been emphasized. There has been an emphasis on the complex ways in which legacies and memories of previous systems impact on change processes and on how informal norms continue to exert influence in new institutional settings and structures.

Within these literatures, there is a notable resistance to the uncritical transfer of conceptual schemes and specific hypotheses from elsewhere, be it from the so called 'mainland' or from developed capitalist democracies. Above all, crude generalisations about island or post-communist spaces per se, are rejected in favour of nuanced and contextual analyses which are based on what might be termed conjunctural methods. Thinking conjuncturally involves an examination of the different, and sometimes divergent, tendencies at work in a particular spatial location at a particular moment in time. It is the particular combination or condensation of these tendencies or forces which constitutes a conjuncture [16]. As Clarke has recently argued: "In such a perspective, the search for the primary cause represents a mistaken analytical route - even if a prime mover was identifiable, it only gains its significance in its articulation with the other tendencies that together make up this specific conjuncture." [16]. Conjunctural thinking contains within it a certain kind of historical thinking, insofar as understanding what Foucault called 'the history of the present' forces us into a critical examination of how the current conjuncture came about, what are its 'genealogies', or its "anterior conditions of existence" [17], the better to understand the future as "an open horizon, fundamentally unresolved, and in that sense open to "the play of contingency" [17]. In addition, whilst spatial thinking is of immense importance, locating spaces within complex systems of interaction, marked by 'geometries of power' [8] in which the local and the global are co-constituted [18], allows for an understanding of social relations and their transformations in ways which reframes supposedly bounded sites as constellations of forces and flows.

It is the case that, within the study of islands, there has been little attention to islands in countries undergoing post-socialist transition. Similarly, within the study of post-socialist strategic development planning, there has been almost no attention to islands. This study thus addresses both the resilience of islands and their heightened susceptibility to change, borrowing a periodisation from political economies of contemporary Croatia which emphasise the significance of multiple transitions: from socialism to post-socialism and from being a part of a federation to national sovereignty and independence (around 1990 and 1991); from war to peace (around late 1995); from authoritarian nationalism to a more democratically oriented government (in 2000); and towards a kind of democratic consolidation and pursuit of EU membership (from around 2003), marked by the transformation and decline of the authoritarian nationalist party that regained power in 2004 and lost it again to the social democratic option in December 2011. 
Our approach reflects our own active engagement in many elements of the unfolding contest to take islands and islanders seriously, combining scientific research, policy advice and drafting of legislation, and, sometimes, political lobbying. In this sense, the text cannot be considered 'objective' but is rather, reflexive, based on the intense engagement of one of us and our joint commitment to a multi-disciplinary approach. The historical facts have been constructed out of interviews with key personnel from the relevant Ministries and combine with our own, and others', prior research and policy work, to shed light on complex processes, largely at the macro-level which, of course, need to be complemented by more in-depth local case studies [19-21]. How to tell the island story is a question that has to be tackled within this approach too. As a chronically under-researched topic, the danger is that premature judgements are offered on what is central and what is marginal, what is general and what particular, what is complex enough to deserve serious scientific attention and what is trivial and barely needs to be mentioned. Our preference, traceable to Wittgenstein, is for narratology rather than epistemology $[22,23]$ which means that Croatian islands' differentia specifica has to be exposed as a set of premises rather than conclusions enabling the reader to arrive at his/her own judgement. Islands are approached here not only as a scientific subject but also as a specific development issue that should be taken care of by elected policy makers in the context of citizen/islander participation.

\section{THE CROATIAN ISLANDS: A BRIEF HISTORY OF DISEMBARKATIONS}

As the technological means of observing and counting physical geographical features have improved over time, the number of islands off the coast of Croatia has grown apace, as have tourist numbers. All other demographic and social indicators, however, have shown a declining trend. The first estimates were made by the Austrians at the end of the 19th century, coming up with a figure of some 650 islands. After WW2, this number increased to 1,185. Most recent research suggests some 1,246 islands, divided into 79 islands proper; 526 small islands or islets; and 641 rocks, either permanently or temporarily visible [24].

Table 1 below shows the total population of the Croatian islands as recorded by each census since 1961, indicating a gradual decline with a notable exception of the decade 1981-91 and a minor one of the decade 2001-2011. Table 2 below shows the age structure of the Croatian islands in 2001 illustrating both an older population and a higher dependency ratio in the islands compared to Croatia as a whole. ${ }^{1}$

The expansion in the 1980s was a result of both 'pull' factors, in terms of the rapid growth of tourism and, hence, rising standard of living and increased employment opportunities for even those with only basic secondary education, and 'push' factors in terms of economic crisis in the urban areas. Currently, some 2.89 per cent of the Croatian population are registered as living on one of the 47 inhabited islands (48 in 2001). The last island in the Adriatic which had one inhabitant only is now recorded as uninhabited. The total figure has never been above some 3.0 per cent, reaching a peak of 173,503 as recorded by the 1921 census. The UNESCO concept that 'small islands' are those with a surface area of less than $10,000 \mathrm{~km}^{2}$ and/or with less than 50,000 inhabitants [27] does not fit the Croatian context. Indeed, only two Croatian islands exceed $400 \mathrm{~km}^{2}$ (Cres and Krk), with none of the Croatian defined 'small islands' bigger than $20 \mathrm{~km}^{2}$. The 47 inhabited Croatian islands range

1 The last Census took place at the end of March 2011. Apart from the basic population numbers across settlements the results have not been published as yet. However, low natality and high mortality rates in the period 2001-2010 confirm that the island population increased due to immigration only. The trend depicted in Table 2 therefore continues. 
Table 1: Population in the Croatian islands, 1961-2011.

\begin{tabular}{ccc}
\hline Date & Population & Index \\
\hline 1857 & 117,481 & 67,7 \\
1900 & 166,891 & 96,2 \\
1910 & 173,263 & 99,9 \\
1921 & 173,503 & 100 \\
1931 & 165,624 & 95,4 \\
1948 & 151,835 & 87,5 \\
1953 & 150,073 & 86,5 \\
1961 & 139,798 & 80,6 \\
1971 & 127,598 & 73,5 \\
1981 & 114,803 & 66,2 \\
1991 & 126,447 & 72,8 \\
2001 & 122,228 & 70,4 \\
2011 & 125,082 & 72,1 \\
\hline
\end{tabular}

Source: [25, 26] and Statistical Report No 1441, The Croatian Bureau of Statistics 2011.

Table 2: Age structure, Croatian islands and general population, 2001 census.

\begin{tabular}{lcc}
\hline Age & Islands & General Pop \\
\hline $0-19$ & $22 \%$ & $24 \%$ \\
$20-59$ & $51 \%$ & $54 \%$ \\
$60+$ & $27 \%$ & $22 \%$ \\
\hline
\end{tabular}

Source: CBS and [26].

in population from 2 (on Srakane Male) to 19,286 (Krk) followed by Korčula $(15,489)$, Brač $(13,987)$ and Hvar $(10,948)$ as the only islands with a population of over 10,000 [26]. In total, there are 313 settlements (naselje), with only 12 having a population of 2,000 or more (Table 3).

Economic activity remains rather simplified when compared to continental Croatia, with islanders, on the whole, having proved able to utilise quickly comparative advantages created by developments on the mainland and create a monocultural production structure. However, the ability to restructure island economies when these comparative advantages ceased to exist proved rather more difficult and, in many cases, impossible. The share of islands in the Croatian economy never exceeded 5 per cent, whatever the indicator, with share in GDP not exceeding 3 per cent. For the past decades, investments in islands represented between 2 and 5 per cent of overall investments. The true value of tourism cannot be calculated as the number of tourist nights is, itself a very crude and, indeed, sometimes unreliable, indicator. Traditionally, there has been a gap between the more developed Northern islands (in the Kvarner bay) and the less developed Southern islands (in South Dalmatia). Table 4 below shows this in terms of the percentage of the active population and rates of unemployment. Again, data from the 2001 Census appear as the most recent published in final form. Given the economic crisis and rising unemployment that Croatia has been undergoing since 2008, the situation on islands could only worsen. 
Table 3: Size of settlements on Croatian islands, 2001.

\begin{tabular}{lcccc}
\hline Settlement size & No. of settlements & \% of total & No. of inhabitants & \% of total \\
\hline 0 & 10 & 2.89 & 0 & 0 \\
$1-50$ & 83 & 26,82 & 1,664 & 1.36 \\
$51-100$ & 54 & 17.25 & 3,898 & 3.19 \\
$101-200$ & 52 & 16.61 & 7,744 & 6.34 \\
$201-500$ & 56 & 17.89 & 17,491 & 14.31 \\
$501-1000$ & 22 & 7.03 & 16,345 & 13.37 \\
$1001-2000$ & 24 & 7.67 & 35,677 & 29.19 \\
$2001+$ & 12 & 3.83 & 39,409 & 32.24 \\
\hline
\end{tabular}

Source: [13] and Statistical Report No 1441, The Croatian Bureau of Statistics 2011.

Table 4: Active population and rates of unemployment in the Croatian islands, 2001.

\begin{tabular}{lrrrrrrr}
\hline & & \multicolumn{5}{c}{ Active population } \\
\cline { 3 - 8 } & & & \multicolumn{2}{c}{ Employed } & \multicolumn{2}{c}{ Unemployed } \\
\cline { 3 - 8 } Island group & Total pop & Total & $\%$ & Total & $\%$ & Total & $\%$ \\
\hline Kvarner & 38,687 & 17,007 & 43.96 & 14,434 & 84.87 & 2,573 & 15.13 \\
N. Dalmatia & 22,565 & 7,956 & 35.26 & 6,230 & 78.31 & 1,726 & 21.69 \\
C. Dalmatia & 42,159 & 17,125 & 40.62 & 13,364 & 78.04 & 3,761 & 21.96 \\
S. Dalmatia & 19,007 & 7,926 & 41.70 & 6,039 & 76.19 & 1,887 & 23.81 \\
All Dalmatia & 83,731 & 33,007 & 39.42 & 25,633 & 77.66 & 7,374 & 22.34 \\
All islands & 122,418 & 50,014 & 40.86 & 40,067 & 80.11 & 9,947 & 19.89 \\
\hline Sounce
\end{tabular}

Source: Lajić and Miše.

Transformations in the economic and social history of Croatian islands of which dramatic demographic changes are a symptom have rarely been caused by islanders and their propensity for change, but by something or someone that came from the sea. Only one or two bigger islands managed to master their development at some points in history as a result of some particular circumstances on the mainland. The economic and social history of small islands in Croatia is a nonlinear narrative of varied and various uninvited but irresistible disembarkations, from the ancient Romans, through the city state of Venice, to the French who ended feudalism and made room for Austrians who disembarked around 1820 and stayed for the next hundred years.

It was a notable moment as former rulers did not interfere in what islanders were producing and how and only took toll, mainly in kind. This was an exploitation which was concerned, only, with expropriating the final product and/or the wealth which came from it. Austrian soldiers and clerks were followed by investors who brought new technologies and know how and were not interested in islanders' skills and knowledge about the ecosystem which enabled them to live sustainably for centuries. Nevertheless, they imposed new labour processes and brought new forms of time-work discipline. The fishing industry, wine production and to some extent ship building were the first to experience a new way of making a living: work organized by someone else, no participation in 
production decision making and wages that could be spent to buy goods that were not produced on the island. Capitalism introduced in this way gradually made islands knots in a continent- wide network of the spatial division of labour. In this phase, autarchy was slowly abandoned to make room for a specialized island economy dependent on whatever fluctuations and investment waves took place on the mainland. The islands faced the paradox of two policies; one made by islanders who continued to live in the old sustainable way wherever and whenever they could and another, colonial and resource stripping, made and implemented by Austrian rulers. Since access to the sea was more important than island resources however, the islands were far from the main focus of the Vienna court, and the neglect of island specificities and lack of care about their resources started to have other kinds of negative effects.

In the early 20th century, the Austro-Hungarian empire was replaced by Italy in the north and by the Kingdom of Yugoslavia in the south Adriatic. Development policy remained dualistic although most resources were already utilized or near exhaustion except for one, perhaps the most valuable and still available, namely islanders themselves. This last resource was not utilized on the islands however and most islanders left for the mainland ending up in both Americas, in Australia, and elsewhere. Island specificities, or rather the differences between the islands and the mainland, became sharper but the top down policy did not respond, as the negative effects accumulated further and agriculture and fishing were slowly abandoned triggering a decline of corresponding crafts.

\section{ISLANDS UNDER SOCIALISM: BELATED RECOGNITION, LIMITED PARTICIPATION}

The next ruler, from 1945 to 1990, was socialist Yugoslavia. The first to disembark after the state militia were socialist planners who brought the idea of concentrating industry and collective ownership of agricultural land. Numerous small canneries and industrial workshops were thus dismantled and transported from smaller islands to bigger ones or to the mainland as part of the policy labelled as "the socialist accumulation of capital" [28]. In classic central planning, regional specificities and local economic effects were disregarded and locals had no say whatsoever. Social effects were not considered either with the final goal, a perfect communist society, seemingly valuable enough to sacrifice a small island or two. The era of top down policies with no participation by islanders reached its peak in the early 1950s, leading to a mass exodus of islanders. The figures in Table 1 show the sharp decline described by the censi of 1948 and 1953. An enclave of remaining islanders on small islands was no longer able to reproduce themselves let alone create any kind of development policy.

In the late 1950s, in contrast to most countries in Central and Eastern Europe, Croatia as a part of socialist Yugoslavia introduced participation at the local authority or municipal level, following the introduction of so-called socialist self-management as an intrinsic part of 'the Yugoslav exception' after the break with Stalin and the Soviet Union. The system revolved around Workers' Councils as organs of workers' control in all enterprises. Some research revealed that decision-making remained top-down and non-transparent, with informal and impenetrable groups of enterprise managers and senior party officials in control, and the Workers' Councils existing as a largely powerless, rubber stamping, body, with as few as 2-3 per cent of all decisions being made and implemented in a truly participatory manner [29, 30].

Correspondingly, Croatia's 118 municipalities, or units of local self-government, were underpinned by a system of socialist democracy. Again, the reality was somewhat different, with members of the Municipal Assembly and the Municipal Executive Council elected from the list proposed by the Socialist Alliance of Working People, a universal and formally non-political body which was, actually, largely politically controlled, and which monopolised power. Municipalities produced an annual 'Social Development Plan' which was an administrative document which was endorsed politically, 
but with no citizens' participation whatsoever. In practice, these documents became more and more formalistic with each successive plan involving rewriting and adjusting the previous year's document. This kind of planning did not survive transition and was abandoned in the early 1990s.

Municipalities also commissioned occasional Physical Plans which were produced by licensed consultancy firms. These boiled down to land use plans inspired more by the development aspirations of the municipal leadership than on basic economic and social analysis. Physical plans tended to be produced on a four to five year cycle in tourist areas, with a longer gap of between ten and fifteen years elsewhere. These documents involved a kind of passive participation which boiled down to public hearings of draft plans previously prepared by licensed physical planners. The key parts of the documents, in terms of land use and spatial development goals, were drawn up under the influence of the Mayor and the Executive Council but with no other stakeholder input whatsoever. Draft plans used to be presented in a non-user-friendly form so that even educated readers could not see clearly what was being proposed. Future land use usually remained blurred to future land users, so that changes in response to public concerns were, nearly always, merely cosmetic. The practice of producing physical plans, underpinned by an architecture of laws, regulations and decrees, survived independence and transition. It remains a legal obligation to produce such plans, with violations of the plan itself a breach of the law. Hence the profession of physical planners, committed only to ex post participation, has maintained a dominant position, enjoying legal protection and support, often favoured for relevant ministerial positions, and maintaining a market niche. Whilst islands were not the focus of attention in this period, there was an opportunity to begin influencing their own development although small islands already were faced with large-scale out migration and large islands became reliant, from the 1960s onwards, on growing tourism and declining industries.

In general terms, the Croatian islands were not in the focus of planning discussions during socialism. In part, this was a reflection of the heavy emphasis on industrialisation and consequent urbanisation in post-WW2 Croatia and Yugoslavia. Even in the early days of the expansion of tourism as a special focus area in Croatia, there was still less attention to islands qua islands than as a part of coastal municipalities. Islands remained undeveloped in terms of tourism, mainly as a result of the higher costs of development in terms of materials, labour and, above all, transportation. The larger islands began to be developed first but, again, tourist capacity remained quite small until the 1980s.

In 1985, the Island Development Co-ordination was formed as a consultative body consisting of the mayors of island municipalities. This is the first of many examples of a kind of 'accidental' policy initiative, with one key figure, the Head of the Department for Islands in the Association of Dalmatian Municipalities (de facto the Dalmatian region), committed to the idea and encouraging mayors to join. The Co-ordination acted as a kind of lobby group and managed to ensure that an item in the Republic budget be established for island development. Mayors joined together to fight for this budget line and competed with each other for their share of it. The dialogue between the Government and the Co-ordination was, thus, established in the absence of any other stakeholders, with both sides assuming and claiming that mayors, a priori, represented islanders' best interests. In part, this reflected a long standing absence of the notion of 'stakeholder' or even 'interest group' under socialist self-management where everyone was assumed to be involved in decision-making albeit in the absence of real and meaningful mechanisms for true participation [31]. Bottom-up initiatives which were not filtered through the Socialist Alliance of Working People were treated as deviant, non-institutional, ill conceived in the eyes of socialist politicians, and, certainly, unwelcome.

The Co-ordination is of particular interest, not least because no similar bodies emerged for other specific geographic areas such as the mountainous or plateaux areas. Its acceptance by the Government can only be explained in terms of the specificities of islands which the state could not handle 
through its normal policy measures and processes. Even here, though, it could be argued that the body was accepted because of the small number of islanders and the corresponding lack of any threat to the existing political system. Policy makers were able to argue that they had responded to and recognised the specificities of islands and institutionalised their concerns in this body. Indeed, speaking in terms of its legacy, it appears that the Co-ordination established a trend, continuing to the present day, of high levels of rhetoric, low levels of funding, and extremely low levels of general popular participation. It cemented in islanders' thoughts the idea that, along with discourses from high officials regarding 'our 1000 beauties' will come little or nothing in the way of money and required projects.

Another initiative of the same period was, however, more participatory and, perhaps, has left a more positive legacy. In 1986, during the first flowerings of social movement activity in parts of Slovenia and Croatia [32], a new initiative emerged based on a kind of 'accidental' common ground between the then President of the Municipal Assembly and researchers from the Institute of Economics Zagreb (EIZ). In the municipality of Cres and Lošinj, two islands joined on the more developed northern Kvarner archipelago, a Centre for the Development of the Adriatic Islands was planned and established in 1987 with two employees funded by municipal funds. Its goals included helping to steer island development, ensuring that development programmes and thinking took into account the specificities of island development, and, crucially, to promote the role of islanders in decision making. From its inception, the Centre came up against the dominant power structure on the islands of Cres and Lošinj, namely the two main tourist and trade firms which employed almost 60 per cent of all the islands' active population, and which controlled municipal decision-making with its own people as Presidents of the Municipal Assembly and Executive Council. Indeed, a number of 'company islands', i.e. those dominated by one major company, still exist today, with companies tending to by-pass participatory planning processes. Traditionally, the two key political positions in the town were nominees of these firms and, when the President of the Assembly changed, municipal commitment changed to concern, if not hostility, at a body perceived to be interfering in municipal matters. Already, by 1988 funding from the municipality became more erratic, invitations to key meetings were no longer received, and the Centre's work was largely ignored.

Formally, the initiative survived the change in the political system in 1991 but never had much power locally. It was formally closed in 1994 although, as we shall note below, elements of the Centre's structures and its leading activists became important in terms of the formulation of island policy at central state level. Overall, then, we can summarise the 1980s as a period of a flowering of interest in islands but with limited participation beyond political and business elites.

\section{ISLANDS IN WAR: ISLANDS OF PARTICIPATION IN A SEA OF CENTRALISATION}

Not surprisingly, in the early 1990s, island development was rather lost as a political issue in the context of more pressing issues in terms of Croatia's independence and the war which, between 1991 and 1995, affected significant parts of Croatia including the islands, largely indirectly in terms of blockages from the sea or to the occupied mainland [33]. More generally, war brought the need for crisis management in government so that it would have been surprising if questions of strategic development could have forced themselves onto the agenda. Changing circumstances necessitated forms of decision-making which had no room for any participatory processes. Over and above this, in part as a result of the combination of the gaining of independence (state-building), and the war and lack of Governmental control over part of the territory (state-destruction), there was a renewed centralisation of state functions in the context of a growing political authoritarianism [34].

This centralisation was, itself, complex since the power of local actors was eroded through the rapid expansion of the number of municipalities in Croatia, from the pre-war level of 118 to 556 
municipalities and towns in 2011. In addition, larger regional units were abolished in favour of 20 counties plus the city of Zagreb [35]. These changes further eroded the possibility of islands being a coherent part of the governmental structure, as they were increasingly divided in terms of a number of municipalities and, in one case (the island of Pag) between two counties. There were 9 island and 7 coastal - island municipalities in 1991. By 2008 this had risen to 54 island towns and municipalities and 8 coastal - island towns and municipalities. A correspondence in terms of an island being covered by one municipality occurs in only five cases (Vir, Dugi otok, Šolta, Lastovo and Mljet). The war consequences led, of course, to a massive decline in tourist numbers and to the turning over of a number of tourist facilities to accommodate a massive number of refugees and internally displaced persons. Overall, the war years saw the introduction of forms of governance incompatible with a modern market economy and light years away from participatory democracy, so that Croatia's transition, and island development and participation along with it, was delayed.

At the same time, and again largely as a result of an 'accidental' meeting of minds between researchers from the Institute of Economics, the former secretary of the now abolished Island Development Co-ordination and the then Minister of Transport and Seamanship, the Lošinj Centre was revived and upgraded and became the designated Centre for Island Development in the Ministry, established in 1993 as the administrative body responsible for decisions regarding the disbursal of the state budget for islands which then stood at between 5 and $6 \mathrm{~m}$ Croatian kuna (HRK) (now about $0.8 \mathrm{~m} \mathrm{EUR).} \mathrm{Three} \mathrm{aspects} \mathrm{of} \mathrm{this} \mathrm{are} \mathrm{important} \mathrm{in} \mathrm{terms} \mathrm{of} \mathrm{the} \mathrm{legacy} \mathrm{of} \mathrm{this}$ for subsequent island development policies. Firstly, it replaced a bottom-up initiative with a largely top-down initiative, incorporating the Centre into the state apparatus. Secondly, in creating a fund and giving the Centre responsibility for disbursal in the absence of agreed mechanisms for prioritization, it created the conditions for political in-fighting, lobbying, the use of informal contacts and, even, corruption. However, thirdly, whilst not, in and of itself, promoting participatory processes, it was a mechanism for continued lobbying for a real commitment to strategic island development, including participation.

In 1993, the new Minister established a new Island Council as a consultative body to the Ministry. It comprised some twenty five island mayors, other "respected public officials" and a small number of scholars interested in islands and their development. This proved, however, to be another "false start', meeting only once before being forgotten, and represented another lost opportunity in terms of opening up participation in island development decision-making. It was a classic case of mutual misunderstanding with the Minister believing that he had fulfilled his duty by appointing the Council but, since he failed to appoint a Secretary or President, in the absence of any Council member taking the initiative, it simply atrophied.

\section{LOBBYING FOR ISLANDS: THE NATIONAL ISLAND DEVELOPMENT PROGRAMME AND RELATED MEASURES}

With the formal end of the war in 1995, a number of important initiatives began reflecting, in some ways, the influence of the former Lošinj Centre on the Ministry itself which, in 1995, was rearranged and changed its name to the Ministry of Reconstruction and Development. One of the major priorities of the new Ministry was to prepare a number of national development programmes including a National Island Development Programme. An inter-disciplinary working group including outside experts was established. Very quickly after this, this group gained the status of a formal Council of twenty five members, although sharing only one common member with the 1993 incarnation. The Council oversaw the preparation of the National Programme, meeting three times, with five of its members playing an active role in its drafting, two of whom had been active in the Lošinj centre and in the Co-ordination in the 1980s. 
In terms of participatory processes, the programme was a step forward. The five persons toured the islands announcing the preparation of the programme and gathering mayors and other stakeholders together for a meeting to garner suggestions. This was, however, the beginning and the end of participation, with discussions on drafts of the Programme reserved for Council members. The reason given was the already time consuming nature of Council discussions and the absence of any administrative or technical support from the Ministry. This was another obstacle which was to repeat itself on a number of subsequent occasions. As part of the new commitment to island development, the budget for islands, now located in the Ministry, doubled to around $10 \mathrm{~m}$. HRK or 1.4.m EUR making it, of course, now even more of a political football.

The National Island Development Programme was adopted by the Croatian Parliament on 28 February 1997. It was also published in a 228 page booklet by the Ministry, representing the most comprehensive overview of island development ever produced in Croatia. Particularly important is Chapter XI, which sets a number of tasks for the national, county, and local government administrations, from the passing of an Islands' Law through to a programme of cultural development on the islands. Each measure noted who should lead the initiative, who should collaborate and, where appropriate, sources of finance. In retrospect, the Programme focuses much less on participatory approaches per se than on the importance of rational strategic planning covering all aspects of island life. However, within this, it is clear that mobilisation of all stakeholders would be a sine qua non of its successful implementation.

In any case, the immediate follow-up hardly boded well for this principle, with the Ministry not accepting the offer of active Council members to initiate and support the implementation of the Programme. It also has to be noted that, in keeping with a kind of legislative approach to reform in Croatia, these Council members saw the preparation of the Law as the most important next step. The inactivity was compounded by the fact that no one was assigned within the Ministry to implement, or even monitor, the programme. The Programme appeared in danger of falling victim to the usual fate of 'strategies' with which Croatia had a 'fascination' in the mid 1990s and beyond, described as "teeming with decisions and intentions about drafting strategies" [36, 37], but with little life breathed into such strategic documents which often, literally, remained on the shelf.

The Ministry only woke up to its obligations after a draft Island Act was prepared and presented to Parliament by three opposition MPs, to make a point against the ruling party. The Ministry engaged an active Council member to prepare the draft Law, overseen by a small four-person Ministerial Task Force. The group of five again toured the Islands, this time presenting the draft law for discussion. In March 1999, faced with two different proposals, Parliament voted for the Government's draft and against the opposition law. Having been somewhat reluctant to pursue the measure, the Government, in a pre-election year, now announced proudly that Croatia had become the third country in the world, following Japan and Finland, to pass an island law.

Crucially, the Act prescribes the preparation of Sustainable Island Development Programmes (SIDPs) covering all the inhabited islands, consolidated as twenty six island groups. These SIDPs were to be contracted and overseen by the Ministry and then adopted both by local government units and Parliament. In addition 14 national, sector-specific State Island Programmes (SIPs), were to be prepared, as well as an Annual National Island Programme containing clear budgetary provisions. The structure provided by SIDPs and SIPs attempted to harmonise top down - bottom up development decision-making and resembled Regional Operational Plans (ROPs) and Sectoral Operational Plans (SOPs) which later became almost compulsory development documents in the EU. The Ministry was also required to produce a standard SIDP methodology to be agreed by Government. It was here that the opportunity for institutionalising participatory processes appeared to exist although, again, the Government's massive increase in the level of state support for islands, set in 
1999 at 89 m. HRK (some $12 \mathrm{~m}$. EUR at today's rates), before the programme planning methods were institutionalised, made it less rather than more likely that financing would follow the plans in any kind of rational way.

\section{OPPORTUNITY LOST OR FOUND?: PARTICIPATORY PLANNING IN REFORM CONDITIONS}

At first glance, the reform-minded Government, a coalition of, until that time, opposition parties, elected in January 2000, offered a European perspective on all aspects of development policy in Croatia and, crucially, had the support of international donors in bringing this about. The new political masters in the Ministry for Reconstruction and Development appeared to be acting quickly, upgrading the Centre to a Department for the Islands headed by an Assistant Minister with, for the first time, over $100 \mathrm{~m}$. HRK (some $13.5 \mathrm{~m}$. EURO) at the Ministry's disposal for financing island development. Still, in the absence of criteria for deciding priorities, these funds were dispersed according to needs and wants as articulated by the mayors. Hence, the entire process remained nontransparent with few checks and balances, with the Department answering only to the Minister, with no formal reporting to Parliament. An index of the fund's importance, in the context of a coalition government, was that the position of Assistant Minister became a highly coveted one, with political in-fighting and turf wars leaving the post unfilled for some five months, with an island politician from one of the coalition partners finally appointed in June 2000. The appointment did not, however, lead to any urgency in terms of implementing the key aspects of the Island Act, with the Ministry failing to live up to its legal obligations to begin the process of contracting the SIDPs.

The impasse continued until April 2000 when, as part of a long-term project on 'Consultancy for Regional Development in Croatia' undertaken by the German state agency Deutsche Gesellschaft für Technische Zusammenarbeit (GTZ) and researchers from the Institute of Economics, permission was sought from the Ministry to be allowed to prepare, with its own funds, the first SIDP in the island of Šolta as a kind of pilot project. Šolta is 9 NM away from the Dalmatian town of Split, covers $58 \mathrm{~km}^{2}$ and, at the time, had a population of 1,300 islanders. The Assistant Minister approved the proposal after some hesitation. The irony, of course, was that here was an externally funded project, involving some of the same researchers as had been involved in the drawing up of the National Island Development Programme, asking permission from the Ministry to undertake a task which was the Ministry's obligation under the Law. The GTZ/EIZ project was rather different from most external development assistance up to that point, being framed much more in terms of flexible programming, genuine partnerships between a small number of external actors and diverse internal stakeholders, and crucially more of a process orientation in which, instead of an obsession with 'successful' outcomes, emphasised learning through doing and the importance of reflexivity and the creation of feedback mechanisms. The project, which began in 2000, aimed explicitly to build local capacity for development planning, to introduce a participatory approach to local development planning and to disseminate the corresponding methodology across the Croatian municipalities and towns on the one hand and through the rapidly growing professional group of local consultants on the other.

GTZ and EIZ consultants arrived on the island for the first time in April 2001, but had to wait another month and a half to begin work because the mayor who agreed to the preparation of the programme lost the municipal elections. The time was used to finally decide how to prepare the programme and what modality of participation was to be used. Informal interviews and a lot of contacts including the candidates for mayor, provided enough information to propose a preliminary list of stakeholders, decide who to approach and how, determine workshop agendas, and so on.

Towards the end of May 2001, after the elections, the new mayor readily accepted the proposition and the analytical work began. An expert in physical planning was found on the island and 
sub-contracted. Others had to be looked for in Split and Zagreb. The analysis was completed in September 2001 containing economic, social, environmental, physical planning and institutional reports and, for the first time in the Croatian context, an analysis of the municipal budget was undertaken. Development stakeholders were identified and, in October 2001, participatory workshops were held with representatives of island interest groups as well as the Ministry discussing problems and defining development goals and a development vision. This was a genuinely innovative approach in the Croatian context and was declared a 'social success' in terms of large attendance, lively discussions, and ultimate agreement on development problems, key objectives, the island's strengths and weaknesses, and the measures needed. The process and end results appeared to be of a high standard and proved that islanders could contribute to meaningful discussions on development priorities and even define development measures and projects i.e. tasks usually reserved for professionals only. Following a month long public consultation process, a draft of Šolta's development programme was completed in February 2002.

On 21 February 2002, the draft programme was presented to the Department for Islands in the Ministry in Zagreb. The Assistant Minister appeared disinterested and made his excuses and left in the middle of the presentation. The Šolta team used the occasion to propose a draft decree on methodology for the preparation of SIDPs which explicitly prescribed a participatory process and insisted upon local adoption of the SIDP. On 1 August 2002, the Decree was adopted by the Croatian Government, establishing a formal framework for implanting participation in development decision-making on the Croatian islands. Of course, as will become clear below, formal frameworks are a necessary but not sufficient condition for changing practices on the ground.

The Šolta SIDP was formally adopted by the Municipal Council in September 2002 and passed to the Ministry. The Department for Islands passed the document to other Ministries for opinions before forwarding to the Government. It was eventually adopted by the Government in November 2003, just before the general election, a full fourteen months after it was adopted on the island. Earlier, in March 2003, a full four years after the passing of the Island Act, the Ministry began the tendering procedure for preparation of the remaining 25 SIDPs, with the last round of contracts with consultancy companies signed in December 2003, including contracts for co-ordination and ex ante evaluation with the GZT/EIZ team. In principle, these moves secured the institutional framework for participatory, top down - bottom up, integrated development management.

Realities proved somewhat at variance with this. On Šolta itself, keen to maintain the momentum and obtain some 'quick wins', GTZ financed two tasks from the Šolta SIDP which were undertaken by local consultants: a feasibility study for the improvement of public services and a tourism master plan. Both documents were adopted by the Šolta Municipal Council but never implemented. On reflection, this was a result of an insufficiently sophisticated institutional analysis and, consequently, a kind of uncritical acceptance of stakeholders' proposals which failed to take account of the low implementation capacity on the island. The tasks put forward by the study and the plan, and, in truth, by the Programme that preceded them, exceeded the administrative capacity of the Šolta municipal administration. Fewer and simpler tasks would have been more likely to have been implemented. The mayor and the municipal council put very little effort into implementation, and limited results were achieved. Most importantly, there was little evidence of any proactive stance in terms of seeking other sources of financing than the state budget. The ownership of Šolta's SIDP was, in the end, vested solely in the person of mayor. The rest of the islanders that attended the workshops as well as the nine existing island municipal administrators were detached from any implementation. In addition the only large firm on the island has been increasing its hotel capacities without any reference to the programme. They did not participate in any aspects of the strategic development programme and did not attend the participatory workshops. 
Similarly, adoption of the programme by Government did not lead to the state meeting its financial commitments as set out in the programme. The Ministry stated that the programme was too late for the fiscal year in question, and that all monies for islands had been spent. Crucially, the fund for island development, which had achieved a status within the Ministry, and a working method for allocation based on 'wish lists', favouritism, and persuasion, took on a life of its own completely unrelated to the process of establishing SIDPs, now coming to be seen as an unstoppable, but really rather irritating, diversion.

\section{PLUS ÇA CHANGE ...: POLITICISED CLIENTELISM VS. PARTICIPATORY PLANNING?}

The new Government, taking power in December 2003, continued the push towards European integration. A major reform of Ministerial responsibilities was undertaken, with the Ministry of Reconstruction and Development rearranged again to become the Ministry of the Sea, Tourism, Transport and Development responsible still for islands. In a sense, this division created a series of contradictions and intra- and inter-Ministerial conflicts at the heart of Government development policy. To update the SIDP story, the remaining twenty five SIDPs were delivered to the Department for Islands in the Ministry by November 2005. The ex ante evaluation confirmed that, whilst of varying levels and quality, all had taken seriously the importance of participatory planning processes. At the same time, the municipality of Nerežišće on the island of Brač, with a total population of 13,400 , adopted the SIDP. The other seven municipalities on the island remained indifferent to the programme, however.

At the same time, a potentially significant change occurred when the Department for Islands made it a requirement that requests for state funding for islands, raised to $214 \mathrm{~m}$. HRK ( $29 \mathrm{~m}$. EUR) in the 2006 budget, be based on proposals in the SIDPs. This created a somewhat anomalous and contradictory situation whereby the Ministry requires implementation of development programmes which have been approved neither by units of local government nor by the central Government. This official use of unofficial documents has, largely, passed without comment or criticism by local government. This may, in part, be because of a fear of upsetting the Ministry which controls the purse strings, but it also appears to be because the SIDPs do present a realistic set of priorities, and have credibility amongst island municipalities. Quite a few mayors approached the Department with requests for financing projects without making any reference to their islands' SIDPs but able, subsequently, to argue that whatever they have proposed already existed there. In this way, participation resulted in lists of projects so exhaustive that even mayors, who usually monopolize development thinking, could not think of anything new. In short, SIDPs, albeit not institutionalised fully, do appear to be based on an appropriate methodology, and have demonstrated the value of participation. The problem is, however, that the allocation of funds has remained non-transparent until today.

On 10 March 2006, amendments to the Island Act were passed by Parliament including, most importantly, the obligation on counties to implement SIDPs if island municipalities are unable or unwilling to undertake such a task. However, Šolta's SIDP remains, years after the completion of all 26 SIDPs, the only one to have been passed to the Croatian government for adoption. The Ministry in charge for implementation of the Island Act that appears uninterested in implementing it has been joined by equally uninterested coastal counties in charge of implementing SIDPs. None of the seven counties which contain one or more islands within their jurisdiction have even asked to see copies of 'their' SIDPs.

Towards the end of 2007 after the national budget had been adopted in the Parliament it was clear to everyone that SIDPs were destined to end up on the shelf alongside with other numerous Croatian development documents that were never implemented. The budget contained the usual item for islands 
as if the National Island Development Programme and 26 SIDPs did not exist and the financing of implementation of the programmes was definitively off the agenda. It seemed that the ever fewer number of islanders who remembered the programmes they participated in could only wait for the next elections. To make things even more pessimistic another ministry, the one in charge for physical planning and environmental protection, failed to ratify the Protocol on Integrated Coastal Zone Management in the Mediterranean which Croatia readily signed as a party to the Barcelona Convention in 2008. The Protocol covers islands and defines and even prescribes integration of all existing plans and programs that deal with development in the overall coastal area. A year or two later it was clear that the Protocol is not going to be ratified and that neglect of islands has become internationalised.

The elections that took place at the end of 2011 brought a significant change as the right-wing party lost the elections after two full mandates. For the second time in the modern history of Croatian parliamentary democracy, a social democratic-led coalition returned to power and announced a European path of development, in line with Croatia being due to join the European Union on 1 July 2013. Less than a year after the elections optimists could claim that the new brooms still need some time to sweep away the old and bring in the new. The pessimists can claim the obvious: notwithstanding cosmetic changes, key decisions regarding island development still appear to be non-transparent and a reflection of a kind of political clientelism [34]. Mayors have learnt that direct communication with the ministry is crucial, leaving the fund, still, to be bargained over and, hence, promoting ad hoc and short-term decision making rather than long-term planning.

\section{CONCLUSIONS: THE LIMITS AND POSSIBILITIES OF PARTICIPATION IN ISLAND POLICIES}

This historically-based overview shows how the practice of central financing has acted as a disincentive for island administrations to increase their own capacity in terms of learning how to deal with development issues, and has left little room for genuine participation. The administration is left to deal with everyday activities only. All development issues are more or less successfully dealt with by the mayor and he or she (almost all are male) is the only one to deal with county and state sources of finance. The main criterion for a good mayor is the amount of money they have managed to garner from non-island sources. In this task, it would seem that informal and political connections are the most efficient and effective in the short-term, which is the only timescale that matters. There is little incentive for participatory processes and procedures leading to capacity building of the island administration, and strengthening of island governance in the medium-term in order to make the island less dependent on central funding in the long-term.

Despite certain gains in each period of the story (Table 5), the complex relationships between political competencies, institutional capacities, and socio-cultural forces continue to work against participatory planning, with broader macro-level political economies seemingly highly mediated in the context of Croatian island development. As noted above, there are real political barriers to participation. The process of so-called decentralisation that has been paid lip service to in Croatia since the early 1990s has, paradoxically, also worked against participation in development decision making. Successive governments have allowed for, and even supported, the establishment of new municipalities and towns so that the 118 municipalities that existed in 1991 had been divided by 2011 into 556 smaller ones. More than a half of these cannot cover their administrative expenditures and are dependent on central financing. In this way, smaller municipalities have become more dependent on central government than ever. Decentralisation, praised as a sine qua non of the development of participatory democracy appears in Croatia more as an act of subtle and non transparent centralisation. Participation is in inverse proportion to centralisation because a chronic lack of finances prompts mayors to seek quick solutions. 
Table 5: Periodising Participatory Planning on Croatian Islands

\begin{tabular}{|c|c|c|c|}
\hline Period & $\begin{array}{l}\text { Macro-Political } \\
\text { Economy }\end{array}$ & $\begin{array}{l}\text { Key Developments in Island } \\
\text { Planning }\end{array}$ & Participation \\
\hline $1945-1980$ & $\begin{array}{l}\text { Socialist Planning / } \\
\text { Later Socialist Self } \\
\text { Management }\end{array}$ & $\begin{array}{l}\text { Limited planning, largely sub- } \\
\text { ordinated to needs of industry; } \\
\text { Some tourism planning }\end{array}$ & $\begin{array}{l}\text { Virtually non-existent - } \\
\text { top-down / expert planning }\end{array}$ \\
\hline $1981-1990$ & $\begin{array}{l}\text { Socialist Self- } \\
\text { management/ new } \\
\text { social movements }\end{array}$ & $\begin{array}{l}\text { Political/expert initiatives; } \\
\text { Island Development Co- } \\
\text { ordination; Centre for Island } \\
\text { Development (interest group) }\end{array}$ & $\begin{array}{l}\text { Limited - mainly expert- } \\
\text { government dialogues; Some } \\
\text { room for local political and } \\
\text { business influence }\end{array}$ \\
\hline 1991-1995 & $\begin{array}{l}\text { War, state-building, } \\
\text { centralisation, } \\
\text { transition }\end{array}$ & $\begin{array}{l}\text { Islands fragmented into many } \\
\text { municipalities; Centre for } \\
\text { Island Development within } \\
\text { Ministry; Island Council }\end{array}$ & $\begin{array}{l}\text { Significant funding but top- } \\
\text { down initiatives dominate - } \\
\text { less needs-based than politi- } \\
\text { cal lobbying. New consulta- } \\
\text { tive bodies left moribund. }\end{array}$ \\
\hline 1996-1999 & $\begin{array}{l}\text { Transition, recon- } \\
\text { struction, neo- } \\
\text { authoritarianism }\end{array}$ & $\begin{array}{l}\text { National Island Development } \\
\text { Programme; (new) Island } \\
\text { Council; Island Act - pre- } \\
\text { scribes SIDPs }\end{array}$ & $\begin{array}{l}\text { Experts toured islands, held } \\
\text { discussions on drafts of pro- } \\
\text { gramme. Strategy unconnect- } \\
\text { ed to monitoring or funding }\end{array}$ \\
\hline 2000-2003 & $\begin{array}{l}\text { Democratic change, } \\
\text { Europeanisation }\end{array}$ & $\begin{array}{l}\text { Dept for Islands within } \\
\text { Ministry; GTZ/EIZ project } \\
\text { on Šolta }\end{array}$ & $\begin{array}{l}\text { Demonstration of value of } \\
\text { participation; Political delays } \\
\text { Implementation limited. }\end{array}$ \\
\hline 2004-present & $\begin{array}{l}\text { Consolidation } \\
\text { of democracy, } \\
\text { EU Candidate/ } \\
\text { Accession Status }\end{array}$ & SIDPs completed & $\begin{array}{l}\text { Existence of participatory } \\
\text { planning and demonstrated } \\
\text { results but low implementa- } \\
\text { tion and continued non- } \\
\text { transparent allocation of funds }\end{array}$ \\
\hline
\end{tabular}

There are only four Croatian islands where the unit of local government is island-wide. Most others consist of between two and seven towns or municipalities, and the smallest islands share a unit of local government either with another island or with the mainland. Informal co-ordination mechanisms do exist on two of the larger islands, Brač and Krk, but these have no mechanism for resolving disagreements. The other divided islands do not even have this, making joint planning and dispute resolution impossible. Overall, on divided islands, then, islanders' potential for participation, so evident in the process of preparation of SIDPs, is not realised. The mayors from the same island often compete for the money at the Ministry, and duplicate plans, for new seaports or even airports, are not uncommon.

There are also infrastructural limitations since investments on islands tend to have higher unit cost than those on the continent. This is a result of a combination of factors including: the cost of transportation of materials and necessary equipment across the sea, and the fact that small-scale investments do not allow for the realisation of economies of scale. The smaller the island, then the more costly is the development of infrastructure. At the same time, the smaller the island, the lower are local fiscal revenues and, consequently, less local funds are available for public investments. 
Consequently, the smaller the island, the greater its dependence on external financing, which lowers the possibilities for the development of efficient participation.

There are some socio-cultural factors which also need to be noted. The preparation of the SIDPs showed that the Northern, more developed, islands have somewhat better mechanisms for the operationalisation of development decisions made in a participatory manner. Their mayors do have interlocutors from civil society which, whilst still in its formative stages, is more visible and vocal here compared to the Southern islands. The less-developed Southern islands' populations are no less willing to participate, however, although the mechanisms for operationalising this participation remain under-developed, and a more paternalistic tradition remains in place. Actually, although more research is needed, the readiness of islanders to participate seems to be greater in predominantly fishing villages and communities than in predominantly agricultural ones. It may be that fishing implies a group effort and high mutual dependence of those involved, with the catch divided amongst fishermen on the basis of the average rather than marginal work input. Agricultural activity on islands is highly individualized and farmers do not depend on each other so that there may be variations in levels of social capital.

In addition, the institutional capacities of many islands in the context of out-migration, coupled with the lack of island identification by some stakeholders (such as business interests), also tends to inhibit the implementation of programmes. The inevitable tension between permanent residents of islands and those who are more concerned to have a week-end or summer retreat is important here, although the role of external business interests as well as island-based companies should not be understated.

The pessimistic conclusion of the story appears to be that only the top down element of strategic planning in terms of island development has been implemented, and this itself in a distorted, and highly inconsistent, way. Some of the contradictions of the top down policy which directly or indirectly discourage participation can be seen from the narrative above. Firstly, the Government adopted a National Programme which explicitly requires islands to be seen as indivisible development units, whilst promoting their division into more and more units of local government. Secondly, the Island Law stipulates a high level of coordination of ministries and public utilities, whereas ministries rarely coordinate and often compete with each other. Thirdly, SIDPs are meant to be the basis for the distribution of state funds, whilst not being formally adopted anywhere. Fourthly, participation in island development decision making is required by means of a government decree, but mayors are still allowed to approach ministries with requests not covered by SIDPs and money is granted on other, non-transparent, criteria.

A more optimistic conclusion might, perhaps, suggest that twin processes of pressure from the process of now certain European integration could combine with an increasing competence, awareness and pressure from civil society organisations to promote good participatory governance. If this is the case, there are enough critiques of the lack of impact of EU policies and programmes in this field, as well as concerns regarding the 'false positives' regarding civil society, to know that any such twin pressures will take a great deal of time. Meanwhile, islanders themselves, who offer no obstacles to the full flowering of participatory processes, will have to wait.

\section{REFERENCES}

[1] Healey, P., Collaborative Planning: Shaping Places in Fragmented Societies, Macmillan: Hampshire, 1997.

[2] Baldacchino, G., Islands, island studies, island studies journal. Island Studies Journal, 1(1), pp. 3-18, 2006. 
[3] Stratford, E., Technologies of agency and performance: Tasmania Together and the constitution of harmonious island identity. Geoforum, 37(2), pp. 273-286, 2006. doi: http://dx.doi. org/10.1016/j.geoforum.2005.03.001

[4] Stratford, E., Flows and boundaries: small island discourses and the challenge of sustainability, community and local environments. Local Environment, 8(5), pp. 495-499, 2003. doi: http:// dx.doi.org/10.1080/1354983032000143653

[5] Baldacchino, G., Island studies comes of age. Tijdschrift voor Economische en Sociale Geografie, 95(3), pp. 272-283, 2004. doi: http://dx.doi.org/10.1111/j.1467-9663.2004.00307.x

[6] Jackson, R., Bruny on the brink: governance, gentrification and tourism on an Australian island. Island Studies Journal, 1(2), pp. 201-222, 2006.

[7] Baldacchino, G., Studying islands: on whose terms? Some epistemological and methodological challenges to the pursuit of island studies. Island Studies Journal, 3(1), pp. 37-56, 2008.

[8] Hay, P., A phenomenology of islands. Island Studies Journal, 1(1), pp. 19-42, 2006.

[9] Kozuch, A. \& Koloszko-Chomentowska Z., The Role of Strategic Planning in Managing Local Development, no date. Available at http://baitas.lzuu.lt/ mazylis/julram/8/222.pdf

[10] Walsh, J., 'Making Space - Making Place', Opening Remarks at SPAN Conference, 2005. Available at http://www.qub.ac.uk/ep/research/span/news/dubconf-oct05/walsh-p01.pdf

[11] Dräger, S., Horvat, Ž., Sumpor, M. \& Starc, N., Vodič za izradu strateških razvojnih programa na lokalnoj razini (Guide for preparing Strategic Development Programmes on the Local Level), EIZG: Zagreb, 2004.

[12] Ciegis, R. \& Gineitiene, D., Participatory aspects of strategic sustainable development planning in local communities: Experience of Lithuania. Technological and Economic Development of Economy, 14(2), pp. 107-117, 2008. doi: http://dx.doi.org/10.3846/1392-8619.2008.14.107-117

[13] Rammel, C., Hinterberger, F. \& Bechtold, U., Governing Sustainable Development (Working Paper No. 1), GoSD: Vienna, 2004.

[14] Flanagan, N., Haase, T. \& Walsh, J., Planning for Change, Combat Poverty Agency: Dublin, 1995.

[15] World Bank, Participation Sourcebook, World Bank: Washington, 1996.

[16] Clarke, J., After Neo-liberalism? Markets, states and the reinvention of public welfare. Cultural Studies, 24(3), pp. 375-394, 2010. doi: http://dx.doi.org/10.1080/09502381003750310

[17] Hall, S., Epilogue: through the prism of an intellectual life. Culture, Politics, Race and Diaspora: The Thought of Stuart Hall, ed. B. Meeks, Lawrence and Wishart: London, pp. 269-291, 2007.

[18] Massey, D., Globalisation as geometries of power, available at http://www.signsofthetimes. org.uk/massey\%5Btextonly\%5D.html, 2002.

[19] Starc, N., Socio Economic Development of the Cres Lošinj Archipelago, UNESCO MAB Programme: Paris, 1989.

[20] Anušić, Z. \& Starc, N., 'Lake Vrana on the Croatian island of Cres: problems of exploitation of a freshwater lake on a small island'. Proceedings from the International Conference: 'Islands 2000', Giardini Naxos, Italy, May, 1992.

[21] Starc, N., Small Islands and Large Scale Development Patterns - story of the Croatian island of Unije. Paper presented to European Regional Studies Association conference, Volos Greece, 30 August -3 September, 2006. Available at http://www.ersa.org/ersaconfs/ersa06/papers/244. pdf (accessed 16 October 2007)

[22] Flyvbjerg, B., Rationality and Power, The University of Chicago Press: Chicago, 1998.

[23] Gasking, D.A.T. \& Jackson, A.C., Wittgenstein as a Teacher, ed. Fann K. T., Ludwig The Man and His Philosophy, Harvester Press: Witgenstein, pp. 49-56, 1967. 
[24] Duplančić-Leder, T., Čala, M. \& Ujević. T., Coastline Lengths and Areas of Islands in the Croatian Part of the Adriatic Sea Determined from the Topographic Maps at The Scale of $1: 25$ 000. Geoadria, 9(1), pp. 5-32, 2000.

[25] Ministry of Reconstruction and Development, Republic of Croatia (MoRD), The National Island Development Programme, MoRD (Croatian language publication): Zagreb, 1997.

[26] Lajić, I. \& Mišetić, R., Island Logarithm: Actual Conditions and Contemporary Demographic Processes in the Adriatic Islands, Institute for Migration and Ministry of the Sea (Croatian language publication): Zagreb, 2006.

[27] Hess, A., Overview. Sustainable Development and Environmental management of Small Islands, eds. W. Beller et al., UNESCO, Man and Biosphere series, 5, pp. 3-14, Paris, 1986.

[28] Stipetić, V., Poljoprivreda kao izvor formiranja akumulacije potrebne privrednom razvoju (Agriculture as a Source of Forming the Accumulation Needed for the Economic Development), Naše teme No 11: Zagreb, 1968.

[29] Županov, J., Samoupravljanje i društvena moć (Self-management and social power), Naša teme: Zagreb, 1969.

[30] Županov, J., Sociologija i samoupravljanje (Sociology and selfmanagement), Školska knjiga: Zagreb, 1977.

[31] Đokić, I., Starc, N. \& Stubbs, P., Participation in Transition: the problems and possibilities of participatory approaches to strategic development management in three localities in Croatia. Paper presented to OECD LEED Centre for Local Development Conference 'Local Development and Governance in Central, East and South-East Europe', Trento, Italy 1-2 June, 2005.

[32] Stubbs, P., New times?: towards a political economy of 'civil society' in contemporary Croatia. Narodna Umjetnost (Croatian J of Ethnology and Folklore Research), 38(1), pp. 89-103, 2001. Available at http://paulstubbs.pbwiki.com/f/NewTimes.pdf (accessed 16 October 2007).

[33] Starc, N., Croatian Islands at War, Insula, Year 1, No. 1., 1992.

[34] Stubbs, P. \& Zrinščak, S., 'Klijentelizam i socijalna politika' (Clientelism and Social Policy', in FES 2 Zagrebački ekonomski forum. 5-18, 2012.

[35] Kordej, D.V. et al., The Spatial dimensions of development in Croatia - from theory to policy vacuum. Proceedings of the 65th Anniversary Conference of the Institute of Economics, Zagreb, eds. Ž. Lovrinčević et al., EIZ: Zagreb, 2005.

[36] Starc, N. et al., Human Development Report, Croatia 2001, UNDP and Institute for Economics: Zagreb, 2002.

[37] Starc, N., Hundred Strategies, One Stratagem - An Inquiry into the Croatian Aptitude to Strategy Production, Seventh International Conference on Enterprise in Transition - Proceedings, Split-Bol, May 24-26, 2007. 